\title{
NEW DEVELOPMENTS IN BRITISH GRASSLAND FARMING
}

\section{How IE*}

The Valets, Whitfield Estate, Allensmore, Herts, Englund

Before discussing grasslaad, it would probably be useful to put United Kingdom agriculture into perspective, and compare total land and its utilization with New Zealand figures. This is summarized in Table 1.

TABLE 1: COMPARISON OF AGRICULTURAL STATISTICS

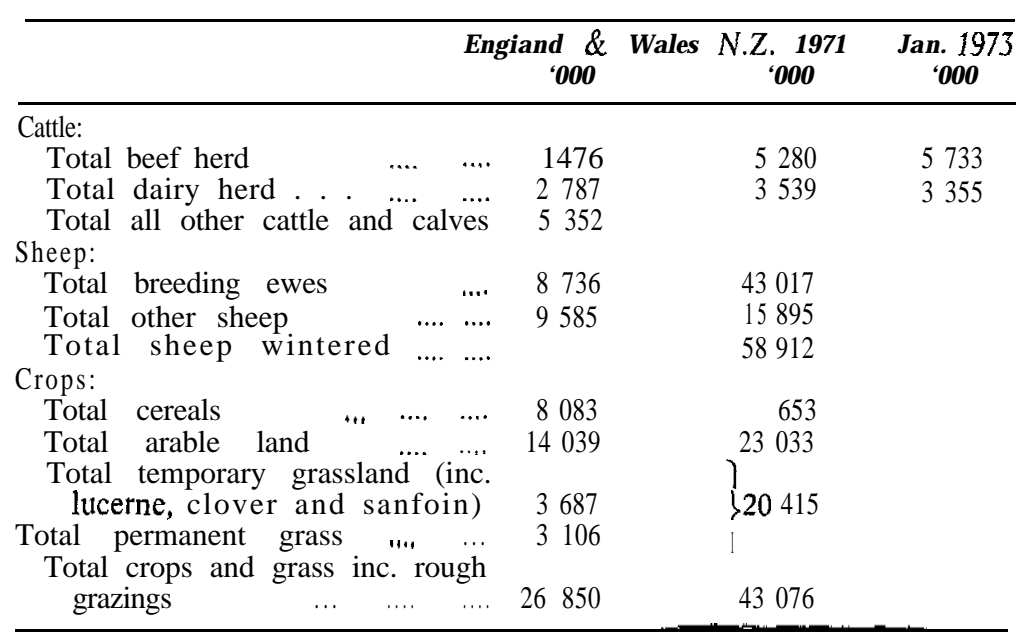

There are great tracts of marginal land in the hill and mountain areas., often moot-land, with little chance of economic improvement, though many of the lower and kinder hills could support more stock. Up until recently, despite the fact that agriculture, in terms of output, is the country's biggest industry, Government policies have tended to curb agricultural output, so as to maintain the import-export relationship, as so many countries we export to can only pay with temperate foods. Production has been rising steadily; the index of net production shows a fore-

* 1973 Nuffield Scholar. 
cast rise for 1972-3 of $17 \%$ over 1968-9, with an estimated gross output for $1972-3$ of $\mathfrak{1 3 1 5 2}$ million.

A quick look at the EEC figures is also relevant in terms of self-sufficiency. The population figures and output figures are given in Tables 2 and 3 .

TABLE 2: EEC FIGURES: POPULATION AND G.N.P.

\begin{tabular}{|c|c|c|c|}
\hline & U.K. & S i x & Nine \\
\hline Total population (million) $\quad .$. & 55.7 & 189.8 & 253.4 \\
\hline Agricultural area (million acres) & 26.5 & 148.0 & 174.5 \\
\hline $\begin{array}{lll}\text { Total G.N.P. } & \ldots .\end{array}$ & 42.3 & 178.1 & 228.0 \\
\hline Agricultural G.N.P. as $\%$ of total", & $" \quad \ldots .2 .9$ & 5.8 & 5.3 \\
\hline Agricultural G.N.P. per worker $£ 1$ & .... 1782 & 1406 & 1434 \\
\hline
\end{tabular}

TABLE 3: EEC FIGURES: SELF-SUFFICIENCY LEVELS 1969-70

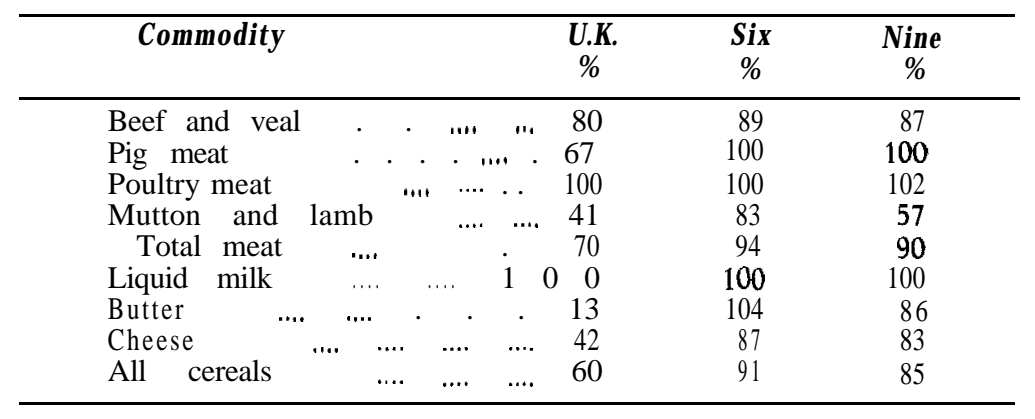

Another useful comparison would be the climatic factors for the United Kingdom and New Zealand. The DSIR figures for Palmerston North are given in Table 4, and Table 5 gives records from the Ministry of Agriculture's Rosemaund Experimental Farm, some 16 males to the east of where I live, where rhe rainfall would be slightly higher and sunshine figures slightly less.

These data show that at Rosemaund rainfall is considerably iess, sunshine, although almost equal in summer, mainly because of our longer summer day length, is only half that of New Zealand in winter, while the 'average temperatures run 2 to 6 " $\mathrm{F}$ lower.

In the United Kingdom growth is considered to be virtually at a standstill when the soil temperature at 4 in. is below 42 " $F$. This means that generally from early November to mid-April little or no growth takes place. 
DEVELOPMENTS IN BRITAIN

TABLE 4: PALMERSTON NORTH WEATHER STATISTICS

(40-YEAR AVERAGE) (DSIR Station)

\begin{tabular}{|c|c|c|c|c|c|c|}
\hline & & & $\begin{array}{l}\text { an Temp. } \\
\left({ }^{\circ} F\right)\end{array}$ & $\begin{array}{l}\text { No. Ground } \\
\text { Frosts }\end{array}$ & $\begin{array}{l}\text { Rainfall } \\
\text { (in.) }\end{array}$ & $\begin{array}{c}\text { Sunshine } \\
(h)\end{array}$ \\
\hline Jan. & & $\ldots$ & 62.7 & 0.2 & 3.0 & 210 \\
\hline Feb. & & $\ldots$ & 63.2 & 0.5 & 3.0 & 182 \\
\hline Mar. & . & & 60.9 & 1.2 & 2.4 & 171 \\
\hline Apr. & . & $\ldots$ & 56.8 & 2.9 & 3.3 & 135 \\
\hline May & & & 51.3 & 7.2 & 3.5 & 115 \\
\hline Jun. & & $\ldots$ & 47.3 & 11.4 & 3.9 & 95 \\
\hline Jul. & & & 46.1 & 14.0 & 3.1 & 108 \\
\hline Aug. & ... & $\ldots$ & 48.0 & 12.2 & 3.5 & 130 \\
\hline Sep. & $\ldots$ & . & 50.9 & 7.0 & 2.9 & 143 \\
\hline Oct. & & & 54.2 & 3.5 & 3.8 & 159 \\
\hline Nov. & & $\ldots$ & 57.3 & 1.0 & 3.3 & 174 \\
\hline Dec. & & & 60.6 & 0.2 & 3.3 & 192 \\
\hline Totals & for & ear & 54.9 av. & 61.3 & 39.0 & 1814 \\
\hline
\end{tabular}

TABLE 5: METEOROLOGICAL RECORDS, ROSEMAUND E.H.F.

\begin{tabular}{|c|c|c|c|c|c|c|}
\hline & & $\begin{array}{c}\text { Mean Air } \\
\text { Temp: (' F) }\end{array}$ & $\begin{array}{l}\text { No. of } \\
\text { Ground } \\
\text { Frosts }\end{array}$ & $\begin{array}{l}\text { Rainfall } \\
\text { (in.) }\end{array}$ & $\begin{array}{c}\text { No. of } \\
\text { Wet Days }\end{array}$ & $\begin{array}{c}\text { Sunshine } \\
(h)\end{array}$ \\
\hline Jan. & $\ldots$ & 37.7 & 21 & 2.3 & 16 & 52.2 \\
\hline Feb. & $\ldots$ & 38.7 & 19 & 1.7 & 12 & 68.7 \\
\hline Mar. & $\ldots$ & 42.5 & 18 & 1.9 & 13 & 111.7 \\
\hline Apr. & . & 46.7 & 13 & 1.8 & 11 & 150.8 \\
\hline May & "' & 51.6 & 6 & 2.3 & 14 & 186.6 \\
\hline Jun. & & 57.5 & 1 & $' 2.0$ & 12 & 201.2 \\
\hline Jul. & $::::$ & 60.6 & - & 2.1 & 12 & 187.0 \\
\hline Aug. & $\ldots$ & 59.9 & & 2.5 & 15 & 166.6 \\
\hline Sept. & $\ldots$ & 55.9 & 2 & 2.4 & 13 & 127.3 \\
\hline Oct. & $\ldots$. & 49.2 & 6 & 2.2 & 14 & 95.8 \\
\hline Nov. & .... & 43.3 & 14 & 2.9 & 15 & 60.4 \\
\hline Dec. & . & 39.8 & 19 & 3.6 & 18 & 48.0 \\
\hline Monthly mea & & 48.5 & 10 & 2.3 & 14 & \\
\hline Annual & total & - & 119 & 27.7 & 165 & 1456 \\
\hline
\end{tabular}

Many-of the soils have a high water-holding capacity and, with lower temperatures and high humidity, losses by evaporation are low. In most parts of the United Kingdom in average years the soils rarely have a deficit of more than 3 in. During the winter months many soils become saturated and unsuitable for outwintering productive cattle, hence some form of housing is an essentiall part of stock farming, as is the need for conserved feed for almost half the year. 
The United Kingdom grass dry matter production with the use oh nitrogen is about the same as in New Zealand but takes place over about $60 \%$ of your growing period, so growth in spring and early summer is more rapid, and much more difficult to control and utilize.

Up until the last few years, with an apparent world surplus of coarse grains, supplementary feeding of cereals was cheap, and so there was not much pressure on grassland, but with barley now costing two and a half times as much as it was three years ago the pressures are on. The pig and poultry industry will be particularly hard hit by rising costs, as will the dairy farmer not managing his grass to its optimum, and relying on large quantities of purchased feed.

Many people, in particular people like Rex Patterson and Stanley Morrey, have been trying to encourage greater reliance on grass, pointing out that often the increased output, stimulated by additional feed, could be uneconomic. Some: of the research institutes, experimental farms, and the fertilizer manufacturers have been stressing the value of adopting a more vigorous approach to grassland farming and there has been an increasing 'awareness among farmers of the. advantage of adopting new techniques, but on the whole grassland output and utilization are still at a fairly . low level in Britain.

A -New Zealand adviser recently returned from Britain made the following comments: "In fact, the biggest potential for increasing productivity from grassland in the' United Kingdom would appear to be- from 'better utilization of pasture that is already being grown rather than from methods to furthır increase pasture yield. . . . Particularly where high amounts of nitrogen were-being used, it was nearly impossible for a sheep $\boldsymbol{\omega}$ see its immediate neighbour lat alone its feet."

It is only fair to point out that the majority of Unrted Kingdom sheep producers use little, if any, nitrogen.

What is being done to improve the situation? There are both commercial and research interests involved here, but, as in all agricultural production, it is often the farmer innovators who make the breakthrough. It is to be hoped that. after the Government's acceptance of the Rothschild report on research and development, more effort and facilities will be, made available to get research. on a farm level and adopted commercially, while maintaining fundamental research at sufficiently high level.

The developments in grassland farming can be basically divided into plant breeding, grazing systems and conservation. 


\section{PLANT BREEDING}

This is mainly taking place at the Welsh Plant Breeding Station, the home of the "S" Strains, the brainchild of George Stapledon in the 1930s.

Breeders have realized that 'breeding grasses within pure agronomic parameters as in the past, with almost complete disregard for the animal, will be of little use in future.

A very big effort is being made at Aberystwyth to isolate the factors involved. An early lead on this was stimulated by the work at the Grassland Research Institute on the relationship between digestible organic matter levels and intake and performance.

It has since been shown that the straight-line relationship first suggested is unreliable, as other factors such as varietal difference and feed combinations can alter the basic relationship and affect intake, as can palatability.

Great effort is now being put into constructing breeders' models. This requires feeds of constant quality and measuring the influence of such factors as digestibility, the index of fibrosity, shear strength, and even splitting plants down into their component parts.

The agronomy department, under Roy Hughes, is also looking at other factors such as height and frequency of defoliation, palatability, persistency, silage and 'hay making suitability, and varietal compatability in mixtures.

This is leading to the production of new breeding material such as high digestible cocksfoots, ryegrasses with high carbohydrate levels or protein, hybrids of tall and meadow fescue and Italian ryegrass, and hybrids of perennial and Italian, which are now on the commercial market. But it will be several years before the "new generation" of grasses will be available.

Besides acting as a source. of information, the agronomy department also 'acts as a test bed for new material on a small scale and over the last few years has planted field-size test blocks on commercial farms for evaluation under farm conditions.

\section{GRAZING SYSTEMS}

More effort is being put into stepping up the utilization through grazing. This is being done by various systems of paddock graz- 
ing, which vary according to farm situation and layout and type of stock, bwt the most usual system is some form of rotational grazing or adjusted set-stocking.

Many of the more progressive dairy farmers have moved over, as have some beef producers, to a "two-sward system", where the grazing areas are laid out in daily paddocks, conservation coming from other areas. An 'adaptation of this by Professor W. Holmes at Wye College entails larger paddocks, but grazing is then controlled by electric fence.

In most cases with the more intensive systems some form of integration of grazing and conservation is practised, where the uneven pattern of grass growth can be manipulated by cutting quite large areas of the grassland for silage early in the season, when the stock demand is low, and grass production at its peak.

Sometimes this is done just by cutting spare paddocks, on other farms which have a two-sward system, where the young animals graze on a third of the area, then, as the regrowth after silage becomes available, they are switched on to the cut area, usually about mid-July, when there is a trough in grass production.

It has been found by research doae by Dr Michel that if calves are drenched and moved on to clean aftermath by around midJuly, there is little risk of parasitism unless they return to contaminated pasture.

Where mixed farming is practised, the use of temporary grass in its first year for calves has a considerable advantage, although even these leys can become infective after mid-summer as the rise in infective larvae usually takes place around July 15.

It has also been found that areas used by cattle during the winter are heavily infected, especially if grazed by younger animals.

It has been found that levels of infection can be reduced by mixing classes of stock in a system, where resistant animals act as vacuum cleaners. Some form of mixed stocking of sheep and beef is ideal. Even better parasite control can be obtained by alternating cattle and sheep on a yearly basis.

It has been found that with productive stock animal performance scon falls once they have grazed down to a certain height, particularly with young beef animals. The work at Hurley with young cattle shows that, if good performance is to be maintained, round 1500 to 2000 lb of dry matter must be left behind (see Fig. 1). 


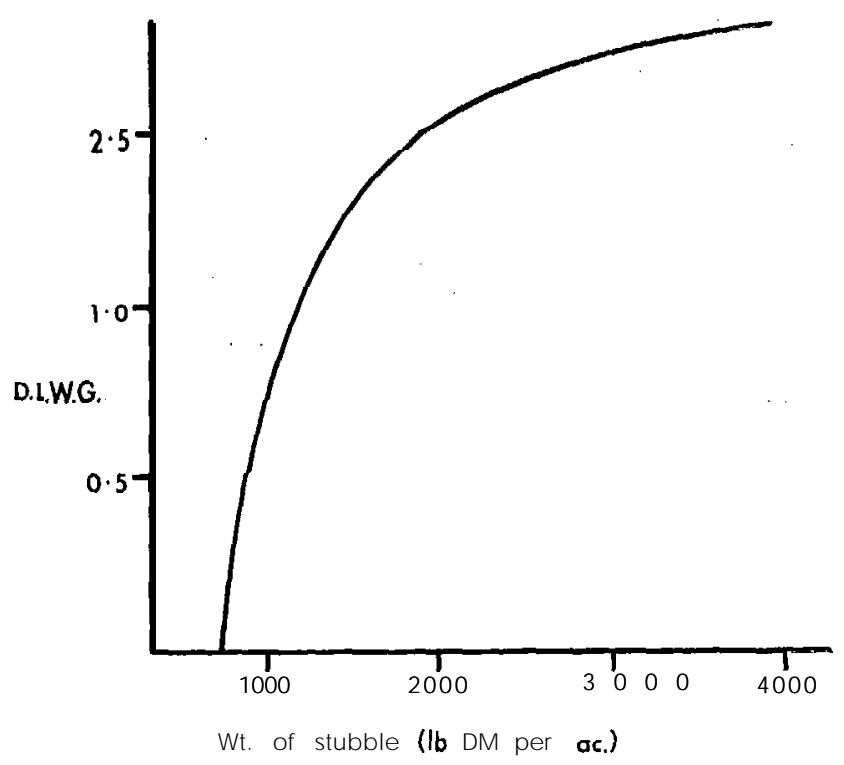

Fig. 1: Relationship between grazing intensity and liveweight of calves (6 to 9 months).

Greater utilization can be achieved by the integration of two or more classes of livestock. In some cases split herd grazing is done where high yielders or rapidly growing cattle precede the lower yielders or other classes of stock which can be held on longer to. clean up pastures.

Work at Rosemaund has sown that, if ewes and lambs are used as scavengers to clear up this surplus, cattle performance can be maintained at a high level and the meat output increased by improved utilization, without any reduction in the cattle stocking rate.

\section{CONSERVATION}

Integration of grazing and silage on the same areas also gives good pasture and parasite control. Silage making, besides being a means of conserving for winter feed, is a tool of grassland management in the production of high quality grazing, and a means of keeping grass under control.

There is a move to the production of younger, higher quality conserved feed and there has been a resurge of interest in grass drying and "in barn hay drying" with the use of cold air fans. 
This system will be stimulated by the introduction of the "Big Bale" in Britain, again a farmer-built machine.

Work at Liscombe has shown definite advantages in using full chop silage in the winter fattening of cattle (Table 6).

TABLE 6: STORE ANIMALS, INTAKE AND PERFORMANCE

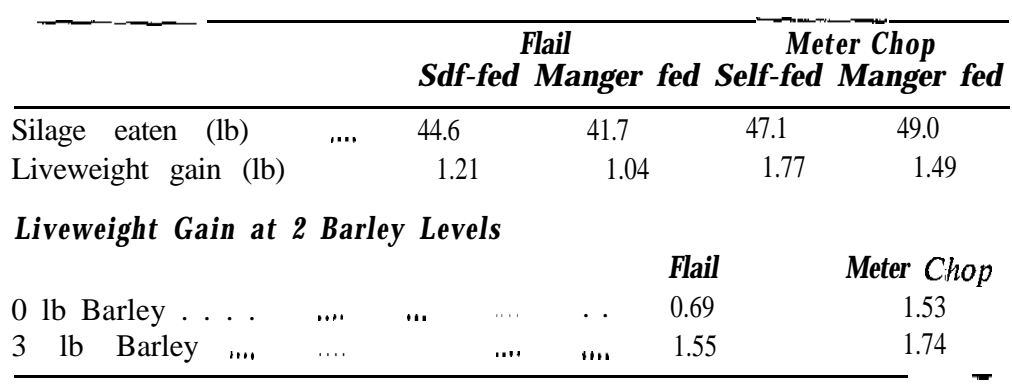

1. The store animals, whether self-fed or manger fed, ate more meter chopped silage than the flail fed stock; this reflected a better rate of winter liveweight gain.

2. When feeding silage alone the meter chop silage gave a significantly greater winter liveweight gain; the addition of $3 \mathrm{lb}$ of barley reduced this advantage to a non-significant level.

3. Feeding meter chopped silage alone gave equivalent winter performance to flail silage supplemented with $3 \mathrm{lb}$ of (barley.

Work at Welsh Plant Breeding Station several years ago showed that in experiments' the addition of dried clover to dried grasses of the same digestibility increased intake and performance, particularly with some species or varieties (Table 7). This has also been the case with silage. The effect of clover in sheep grazing in New Zealand is well known but as yet has nat been exploited in the United Kingdom.

TABLE 7: WELSH PLANT BREEDING STATION DATA ON DRIED FORAGE

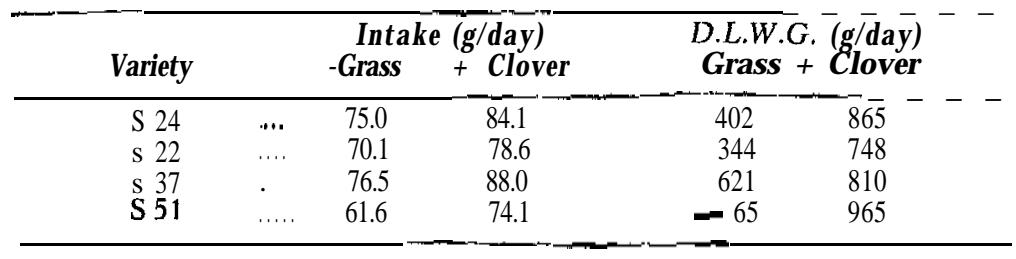




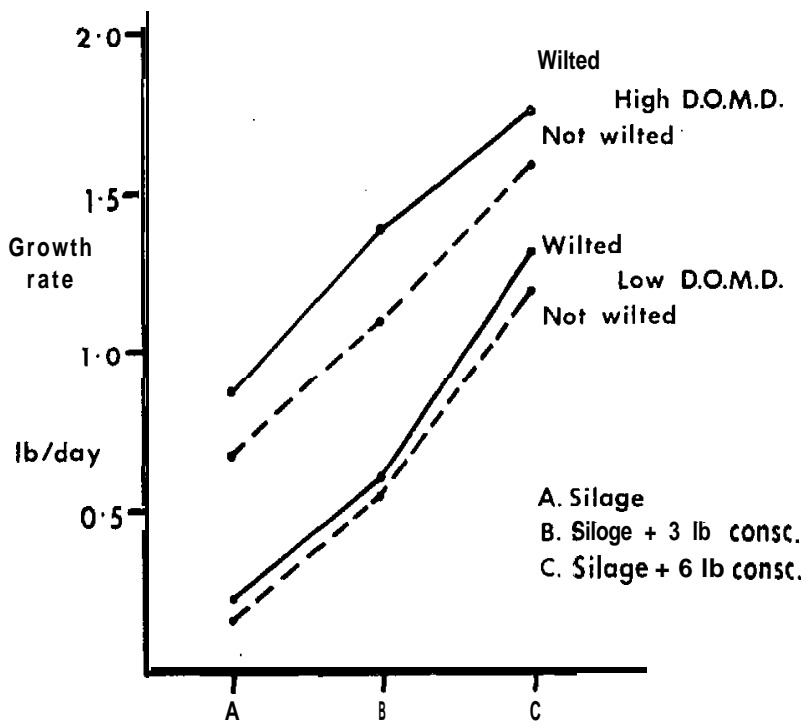

FIG. 2: Effect on performance due to wilting.

The work at Liscombe shows very big advantages in early cutting and wilting (Fig. 2). High quality silage needs less supplementation with cereals. With the use of additives, precision chop harvesters, and cutting at an early stage, wilting before being picked up can lead to lower cost production. Although gross margin per acre may fall by reducing concentrate inputs, the net margin per grass acre is increased.

Over the last few years there has been an attempt to exploit the new techniques available to increase the profitability of livestock production. The main effort has been concentrated on re-

TABLE 8: WINTER FINISHING (All figures refer to per head)

\begin{tabular}{|c|c|c|c|c|c|c|}
\hline & & $1967-8$ & $1968-91$ & $\begin{array}{l}\text { Winter } \\
1969.70\end{array}$ & 1970-t & 1971-2 \\
\hline $\begin{array}{l}\text { Total gain (lb) } \\
\text { D.L.W.G. (lb) }\end{array}$ & $\ldots$ & $\begin{array}{l}251 \\
1.84\end{array}$ & $\begin{array}{l}313 \\
2.12\end{array}$ & $\begin{array}{l}305 \\
2.04\end{array}$ & $\begin{array}{l}355 \\
1.88\end{array}$ & $\begin{array}{l}338 \\
2.10\end{array}$ \\
\hline Concs. fed over winter $(\mathrm{cwt})$ & & 13 & 14 & 10 & 8.1 & 6.5 \\
\hline Concs. fed per d a y (lb) & 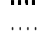 & 9 & 10.6 & 7.9 & 5.1 & 4.6 \\
\hline $\mathrm{Lb}$ concper lb gain & ..., & 5.8 & 5.0 & 3.13 & 2.74 & 2.15 \\
\hline
\end{tabular}


ducing winter feed costs without reducing liveweight gain or delaying fattening.

Red clover is now grown for silage, grass leys cut at very early ear emergence, while quality is high, wilted and picked up with a precision chop harvester fitted with a formic acid applicator. Great care is taken in sealing the grass in the silo to reduce losses through uncontrolled fermentation. This gives a valuable production feed and Table 8 shows the effect on concentrated usage of higher quality feed.

In conclusion, I would like to add two more quotes, the first humorous, but with a considerable ring of truth.

"The more I think about it the more certain I am that grass is high on the list of the most valuable assets we have in the country, certainly rivalling coal and the London School of Economics, yet like the L.S.E. no oae really understands how to manage it, most of all those involved in it."

"The battle will be between the European forage maize ruminant feeder and the British grass ruminant feeder."

The last by Sir W. E. Jones, could become very real over the -next decade and will call for increased effort from all the disciplines involved with all facets of growing and utilization of grass, from the breeders, soil scientists, animal geneticists, nutritionists, but not least from the farmers. 